\title{
Penilaian Prestasi Kerja Pegawai Negeri Silpil di Badan Kepegawaian dan Pengembangan Sumber Daya Manusia Daerah Kabupaten Bungo
}

\author{
Ismail Buhari \\ Widyaiswara Ahli Madya \\ BPSDM Provinsi Jambi \\ Correspondence email: ismailbuhari70@gmail.com
}

\begin{abstract}
Absract. Human resources (HR) is a very important factor that cannot even be separated from an organization, moreover a country or government organization. The success or failure of an organization is very dependent on the ability of human resources in moving management within the organization through the form of effectiveness and efficiency. Human resources are an important asset for the organization because it is closely related to the running or not of other resources. The Bungo Regional Human Resources and Human Resources Agency (BKPSDMD) has an important role in supporting the performance of the government to improve the quality of Civil Servants in the Bungo Regency government environment in order to be able to provide the best service to the community in a professional, honest, fair and equitable manner in carrying out state duties, governance and development. The point is that Civil Servants as one of the main driving factors for the implementation of development both at central and regional levels.To see the performance of apparatus resources in accordance with what is needed or not, an assessment of work performance or performance that is objective is needed. This assessment process must be able to reflect the performance of civil servants in real terms without bias and disagreement. Moving from these thoughts, the authors are interested in conducting research under the title "Performance Appraisal of Civil Servants in the Agency for Civil Service and Human Resources Development in the Bungo District" Civil aims to make research writing and its application become easy and structured. Therefore, the authors limit research on the Performance Appraisal of Civil Servants in the Civil Service and Human Resources Development Agency of the Bungo District. Based on the results of research on the Performance Appraisal of Civil Servants in the Civil Service and Human Resources Development Agency of the Bungo District, the authors assess the Performance appraisal of the Civil Service and Human Resources Development Agency of the Bungo District has been running quite effectively. There are Inhibiting Factors in the Performance Evaluation of Civil Servants in the Civil Service and Human Resources Development Agency of the Bungo District, both internal and external, so that in the future can make efforts in the assessment of work performance. Suggestions from the author to the Civil Service and Human Resources Development Agency of the Bungo District to streamline the Performance Assessment of Civil Servants and overcome the existing obstacles.
\end{abstract}

Keywords: Job Performance Evaluation, Human Resources, Obstacles.

\section{PENDAHULUAN}

Sumber daya manusia (SDM) merupakan salah satu faktor yang sangat penting bahkan tidak dapat dilepaskan dari sebuah organisasi, terlebih lagi sebuah negara atau organisasi pemerintah. Berhasil atau tidaknya suatu organisasi sangat bergantung kepada kemampuan sumber daya manusia dalam menggerakan manajemen di dalam organisasi melalui wujud efektifitas dan efisiensi. Sumber daya manusia merupakan aset yang penting bagi organisasi karena sangat berkaitan dengan berjalan atau tidaknya sumber daya lain. Sama halnya juga di dalam organisasi pemerintahan di dalam suatu negara. Untuk mewujudkan suatu pemerintahan yang baik (good governance), negara harus mampu mewujudkan pelayanan kepada warga negara dengan baik dengan prinsip bersih, transparan dan akuntabel. Tentu semua ini harus di dukung dengan sumber daya yang mumpuni di dalam organisasi tersebut dan salah satunya yang paling penting adalah sumber daya manusia.

Untuk mampu mewujudkan itu semua berdasarkan tuntutan zaman dan tantangan global, diperlukan sumber daya aparatur yang memiliki kualitas yang mumpuni dan berkompeten dalam menjalankan tugas pemerintahan sebagai pelaksana kebijakan publik, pelayanan publik dan alat pemersatu bangsa. Untuk menciptakan itu semua diperlukan peningkatan profesionalisme, semangat perjuangan, dan kemauan untuk selalu berkembang untuk maju. Aparatur pemerintahan sebagai penyelenggara negara dan pemerintah diberikan tanggung jawab dan tugas untuk mewujudkan kesejahteraan masyarakat secara adil dan beradab. Sumber daya aparatur berkaitan dengan implementasi dari sistem-sistem yang ada, salah satunya sistem evaluasi kinerja, dalam hal ini kinerja aparatur dalam penyelenggaraan tugas dan fungsi sebagai pelayanan kepada masyarakat. Juhairiah (2016) mengatakan bahwa kinerja aparatur bisa dilihat dari apa yang telah dilakukan untuk organisasi sesuai dengan target yang telah direncanakan atau dalam hal pemberian pelayanan kepada masyarakat. Kinerja aparatur sendiri sebenarnya bisa saja langsung dinilai oleh masyarakat sendiri terhadap kenyataan yang terjadi di lapangan. Akan tetapi itu semua tidak bersifat objektif dan tidak menggambarkan kinerja aparatur itu sendiri secara menyeluruh. Kusriyanto (1991) dalam Mangkunegara (2012) menyebutkan bahwa kinerja merupakan sebagai output atau hasil kerja sesungguhnya yang dicapai seseorang atau 
Ismail Buhari, Penilaian Prestasi Kerja Pegawai Negeri Silpil di Badan Kepegawaian dan Pengembangan Sumber Daya Manusia Daerah Kabupaten Bungo

sumber daya manusia dalam bentuk kualitas dan kuantitas dalam melaksanakan tugas dan tanggung jawab yang diberikan. Untuk melihat kinerja sumber daya aparatur sudah sesuai dengan yang dibutuhkan atau tidak, diperlukan suatu penilaian prestasi kerja atau kinerja yang bersifat objektif. Penilaian kinerja ini sendiri bertujuan untuk mengevaluasi dan mengetahui apakah tugas-tugas dan tanggung jawab yang diberikan kepada sumber daya aparatur sudah sesuai dengan kemampuan yang dimiliki. Selain itu penilaian prestasi kerja ini juga bisa menjadi landasan dalam pengambilan kebijakan organisasi dalam hal peningkatan kinerja pegawai. Mangginson (1981) dalam Mangkunegara (2012) menyebutkan bahwa evaluasi kinerja atau penilaian prestasi karyawan didefinisikan sebagai suatu rangkaian yang dipakai pimpinan untuk melihat seorang pegawai melaksanakannya sesuai dengan fungsi yang harus dikerjakan dan beban kerjanya.

Dalam pelaksanaanya, pemerintah membuat Peraturan Pemerintah Nomor 46 Tahun 2011 tentang Penilaian Prestasi Kerja Pegawai Negeri Sipil. Kebijakan ini dibuat dalam rangka penyelenggaraan pembianaan Pegawai Negeri Sipil berdasarkan prestasi kerja dan sistem karier dengan berorientasi pada peningkatan prestasi kerja dan pengembangan potensi Pegawai Negeri Sipil. Penilaian prestasi kerja dilakukan oleh pejabat penilai yang merupakan atasan langsung dari Pegawai Negeri Sipil yang bersangkutan. Dalam melakukan penilaian ada 2 (dua) indikator yang dijadikan acuan yaitu Sasaran Kinerja Pegawai (SKP) dengan bobot penilaian sebesar 60\% dan Perilaku kerja sebesar 40\%. Berdasarkan rekapitulasi laporan penilaian prestasi kerja PNS Pusat dan Daerah yang dipublikasikan oleh Badan Kepegawaian Negara Tahun 2016 terlihat bahwa hanya 26 instansi pusat dari jumlah 82 yang melapor dan hanya 343 instansi daerah dari jumlah seluruhnya mencapai 542 yang melapor baik secara manual maupun melalui aplikasi E-Lapkin. Ini tentu terlihat bahwa masih banyak Instansi Daerah dan Instansi Pusat yang belum melaksanakan penilaian prestasi kerja, padahal hal ini telah jelas dikatakan di dalam Undang-Undang Nomor 5 Tahun 2014 tentang Aparatur Sipil Negara mengenai pelaksanaan penilaian prestasi kerja. Peraturan Pemerintah Nomor 46 Tahun 2011 Tentang Penilaian Prestasi Kerja Pegawai Negeri Sipil diharapkan mampu mendongkrak kinerja Pegawai Negeri Sipil untuk bisa bekerja lebih baik lagi. Sistem penilaian yang bersifat terbuka dan objektif, diharapkan dapat meningkatkan motivasi dan produktivitas serta disiplin kerja Pegawai Negeri Sipil, bukan saja dilihat dari absensi finger print semata. Penilaian ini juga digunakan untuk pengembangan karier dan potensi Pegawai Negeri Sipil serta pengembangan manajemen dan organisasi yang bersangkutan. Ini juga untuk melihat secara adil Pegawai Negeri Sipil yang tidak mempunyai capaian kerja yang tidak sesuai dengan rencana dan target akan berbeda dalam pembinaan karier dan dalam hal penghasilan masing-masing individu. Perubahan sistem penilaian kinerja ini juga akan mempengaruhi motivasi dan disiplin Pegawai Negeri Sipil sehingga akan menciptakan efektifitas dan efisiensi organisasi. Selain itu, Pegawai Negeri Sipil masih banyak yang menganggap bahwa prestasi yang dimilikinya sudah cukup dan tidak mau lagi untuk berinovasi lebih maju dalam pengembangan keterampilan dan wawasan.

Kaitannya dengan pelaksanaan pelayanan dan pembangunan di Kabupaten Bungo, Kantor Badan Kepegawaian dan Sumber Daya Manusia Daerah Bungo (BKPSDMD) mempunyai peran yang penting dalam rangka mendukung kinerja pemerintah untuk meningkatkan kualitas Pegawai Negeri Sipil di lingkungan pemerintah Kabupaten Bungo guna mampu memberikan pelayanan terbaik kepada masyarakat secara profesional, jujur adil dan merata dalam melaksanakan tugas negara, pemerintahan dan pembangunan. Intinya adalah Pegawai Negeri Sipil sebagai salah satu faktor penggerak utama terlaksananya pembangunan baik di pusat maupun daerah. Berdasarkan fenomena empiris yang terjadi di Kabupaten Bungo terlihat masih banyak pegawai negeri sipil yang melakukan tindakan indisipliner dengan tidak hadir pada hari pertama masuk kerja pasca cuti hari raya Idul Fitri tahun 2018 saat di sidak oleh Bupati dan Wakil Bupati Bungo ke berbagai OPD. Masih banyak PNS dari berbagai instansi OPD di Kabupaten Bungo yang tidak hadir dengan keterangan tidak jelas. Ini tentu memperlihatkan bahwa tingkat disiplin PNS di kabupaten Bungo masih belum terlalu baik. Hal ini juga tentu akan berpengaruh terhadap penilaian prilaku kerja yang terdapat dalam format penilaian prestasi kerja Pegawai Negeri Sipil. (www.nasionalxpos.co.id tanggal 23 Juni 2018). Hasil pengamatan penulis pada saat melakukan wawancara dengan Kepala Sub Bagian Umum dan Kepegawaian di Badan Kepegawaian dan Pengembangan Sumber Daya Manusia Daerah Kabupaten Bungo ditemukan bahwa masih banyak ditemukan pegawai negeri sipil yang belum mengumpulkan hasil peniliaian capain kinerjanya kepada bagian kepegawaian. Hal ini menunjukan bahwa penilaian prestasi kerja ini hanya sebatas formalitas semata dan hanya digunakan pada saat mengurus kenaikan pangkat dan golongan saja. Sebagai seorang aparatur sipil negara yang melaksanakan manajemen organisasi di instansi daerah harus mampu menunjukan kinerja dengan baik berdasarkan indikator-indikator yang telah ditetapkan. Proses penilaian ini harus mampu mencerminkan kinerja pegawai negeri sipil secara riil tanpa ada bias dan pertentangan. Maksud dari penelitian ini untuk mencari data, faktor dan informasi yang berkaitan dengan pelaksanaan penilaian prestasi kerja Pegawai Negeri Sipil, kemudian mengetahui faktor-faktor penghambat dan cara mengatasi faktor penghambat dalam pelaksanaan penilaian prestasi kerja di Kantor Badan Kepegawaian dan Pengembangan Sumber Daya Manusia Daerah Kabupaten Bungo agar kedepannya dapat terlaksana lebih baik. 
Ismail Buhari, Penilaian Prestasi Kerja Pegawai Negeri Silpil di Badan Kepegawaian dan Pengembangan Sumber Daya Manusia Daerah Kabupaten Bungo

\section{Literatur Review}

Prestasi Kerja

Menurut Dharma dalam Supriatna dan Sukiasa (2012), prestasi kerja adalah sesuatu yang dikerjakan atau produk/jasa yang dihasilkan atau diberikan oleh seseorang atau sekelompok orang. Mangkunegara (2014), kinerja karyawan (prestasi kerja) adalah hasil kerja secara kualitas dan kuantitas yang dicapai oleh seseorang karyawan dalam melaksanakan tugasnya sesuai dengan tanggung jawab yang diberikan kepadanya. Peter dan Yeni dalam Fahmi (2011) mendefinisikan prestasi kerja sebagai hasil kerja yang diperoleh dari melaksanakan tugas yang dibebankan kepada seseorang. Menurut Sedarmayanti (2013) mendefinisikan kinerja sebagai hasil kerja yang dapat dicapai oleh seseorang atau sekelompok orang dalam suatu organisasi, sesuai dengan wewenang dan tanggungjawab masing-masing, dalam rangka upaya mencapai tujuan organisasi bersangkutan secara legal, tidak melanggar hukum dan sesuai dengan moral maupun etika. Berdasarkan beberapa pendapat ahli di atas, bahwa pengertian prestasi kerja juga merujuk kepada kinerja seseorang di dalam organisasi. Antara prestasi kerja dan kinerja mempunyai substansi yang sama di dalam manajemen sumber daya manusia.

\section{Penilaian Prestasi Kerja}

Penilaian prestasi karyawan yang dikemukakan Mengginson (1981) dalam Mangkunegara (2014) adalah penilaian prestasi kerja (performance appraisal) adalah suatu proses yang digunakan pimpinan untuk menentukan apakah seorang karyawan melakukan pekerjaannya sesuai dengan tugas dan tanggung jawabnya. Selanjutnya Sikula (1981) dalam Mangkunegara (2014) mengemukakan bahwa penilaian pegawai merupakan evaluasi yang sistematis dari pekerjaan pegawai dan potensi yang dapat dikembangkan. Penilaian dalam proses penafsiran atau penentuan nilai, kualitas atau status dari beberapa obyek orang ataupun sesuatu (barang). Menurut Dessler dalam Sudarmanto (2009) menyatakan bahwa dengan tujuan orang untuk menghilangkan kemerosotan prestasi kerja. Penilaian prestasi kerja adalah suatu proses yang meliputi: 1) penetapan standar prestasi kerja, 2) penilaian prestasi kerja aktual karyawan dalam hubungan dengan standar, dan 3) memberi umpan balik kepada karyawan. Menurut Mangkunegara (2014) kegunaan penilaian prestasi kerja (kinerja) karyawan adalah: a) Sebagai dasar dalam pengambilan keputusan yang digunakan untuk prestasi, pemberhentian dan besarnya balas jasa, b) Untuk mengukur sejauh mana seorang karyawan dapat menyelesaikan pekerjaannya, b) Sebagai dasar untuk mengevaluasi efektivitas seluruh kegiatan dalam perusahaan, c) Sebagai dasar untuk mengevaluasi program latihan dan keefektifan jadwal kerja, metode kerja, struktur organisasi, gaya pengawasan, kondisi kerja dan pengawasan, d) Sebagai indicator untuk menentukan kebutuhan akan latihan bagi karyawan yang berada di dalam organisasi, e) Sebagai alat untuk meningkatkan motivasi kerja karyawan sehingga dicapai performance yang baik, f) Sebagai alat untuk dapat melihat kekurangan atau kelemahan dan meningkatkan kemampuan karyawan selanjutnya, g) Sebagai kriteria menentukan, seleksi dan penempatan karyawan, h) Sebagai alat untuk memperbaiki atau mengembangkan kecakapan karyawan, dan i) Sebagai dasar untuk memperbaiki atau mengembangkan uraian tugas (job description).

Menurut Rivai dalam Supriatna dan Sukiasa (2010) menyatakan bahwa aspek-aspek penilaian prestasi kerja dapat dikelompokan menjadi: 1) Kemampuan teknis, yaitu kemampuan menggunakan pengetahuan, metode, teknik dan peralatan yang digunakan untuk melakasanakan tugas serta pengalaman dan pelatihan yang diperolehnya, 2) Kemampuan konseptual, yaitu kemampuan untuk memahami kompleksitas perusahaan dan penyesuaian bidang gerak dari unit masing-masing ke dalam bidang operasional perusahaan secara menyeluruh, yang pada intinya individu tersebut memahami tugas, fungsi serta tanggung jawabnya sebagai seorang karyawan, dan 3) Kemampuan hubungan interpersonal, yaitu antara lain kemampuan untuk bekerja sama dengan orang lain, memotivasi karyawan, melakukan negoisasi dan lain-lain. Merujuk dari pendapat beberapa ahli di atas dapat disimpulkan bahwa, penilaian prestasi kerja merupakan suatu proses evaluasi terhadap kinerja atau hasil kerja pegawai di dalam suatu organisasi baik organisasi swasta maupun organisasi publik berdasarkan standar kinerja yang telah ditentukan oleh organisasi yang dilaksanakan secara berkala dengan menggunakan metode dan teknik tertentu guna meningkatkan kinerja organisasi secara keseluruhan.

\section{Pegawai Negeri Sipil.}

Menurut Harsono (2011) definisi Pegawai adalah "orang-orang atau sekelompok orang yang memiliki status karena pekerjaanya. Sedangkan menurut Widjaja (2007), pegawai adalah orang-orang yang dikerjakan di dalam badan tertentu, baik di Lembaga-lembaga pemerintah maupun dalam badan-badan usaha. Kemudian Anggraeni (2017) mendefinisikan Pegawai Negeri Sipil (PNS) sebagai warga Negara Indonesia yang telah melewati seleksi kemudian diangkat oleh pejabat Pembina Kepegawaian untuk menduduki jabatan pemerintahan. Harsono (2011) menyatakan bahwa pegawai Negeri adalah setiap warga Negara Republik Indonesia yang telah memenuhi syarat yang ditentukan, diangkat oleh Pejabat yang berwenang dan diserahi tugas dalam suatu jabatan negeri, atau diserahi tugas negara lainnya, dan digaji berdasarkan peraturan perundang-undangan yang berlaku.Pegawai Negeri adalah setiap warga 
Ismail Buhari, Penilaian Prestasi Kerja Pegawai Negeri Silpil di Badan Kepegawaian dan Pengembangan Sumber Daya Manusia Daerah Kabupaten Bungo

negara Republik Indonesia yang telah memenuhi syarat yang ditentukan, diangkat oleh pejabat yang berwenang dan diserahi tugas dalam suatu jabatan negeri, atau diserahi tugas negara lainnya, dan digaji berdasarkan peraturan perundang-undangan yang berlaku. Undang-Undang RI Nomor 43 Tahun 1999 tentang Pokok-Pokok Kepegawaian Pasal 3 Ayat 1 menyatakan bahwa Pegawai Negeri berkedudukan sebagai unsur aparatur negara yang bertugas untuk memberikan pelayanan kepada masyarakat secara profesional, jujur, adil, dan merata dalam penyelenggaraan tugas negara, pemerintahan, dan pembangunan". Kemudian dalam Pasal 12 Ayat 2 Undang-undang Republik Indonesia Nomor 43 Tahun 1999 tentang Pokok-Pokok Kepegawaian mengemukakan bahwa: Untuk mewujudkan penyelenggaraan tugas pemerintah dan pembangunan sebagaimana dimaksud dalam ayat (1), diperlukan Pegawai Negeri Sipil yang profesional, bertanggung jawab, jujur, dan adil melalui pembinaan yang dilaksanakan berdasarkan sistem prestasi kerja dan sistem karier yang dititikberatkan pasa sistem prestasi kerja.

Selanjutnya dalam pasal 20 mengemukakan bahwa untuk lebih menjamin obyektivitas dalam mempertimbangkan pengangkatan dalam jabatan dan kenaikan pangkat diadakan penilaian prestasi kerja. Pada Undang-undang Nomor 5 Tahun 2014 tentang Aparatur Sipil Negara (ASN) disebutkan pada pasal 1 yaitu: 1) Aparatur Sipil Negara yang selanjutnya disingkat menjadi ASN adalah profesi bagi Pegawai Negeri Sipil dan pegawai pemerintah dengan perjanjian kerja yang bekerja pada Instansi pemerintah, 2) Pegawai Aparatur Sipil Negara yang selanjutnya disebut Pegawai ASN adalah pegawai negeri sipil dan pegawai pemerintah dengan perjanjian kerja yang diangkat oeleh pejebat Pembina kepegawaian dan deserahi tugas negara lainnya dan gaji berdasarkan peraturan perundang-undangan, dan 3) Pegawai Negeri Sipil yang selanjutnya disingkat PNS adalah warga negara Indonesia yang memenuhi syarat tertentu, diangkat sebagai pegawai ASN secara tetap oleh pejabat Pembina kepegawaian untuk menduduki jabatan pemerintah. Peraturan Pemerintah Nomor 46 Tahun 2011 tentang Penilaian Prestasi Kerja Pegawai Negeri Sipil Pasal 5 Angka 2 mengatakan "Sasaran Kerja Pegawai memuat kegiatan tugas jabatan dari target yang harus tercapai dalam kurun waktu penilaian yang bersifat nyata dan dapat diukur". Kemudian dijelaskan dalam Penjelasan Atas Peraturan Pemerintah Nomor 46 Tahun 2011 Tentang Penilaian Prestasi Kerja Pegawai Negeri Sipil Pasal 7 Ayat 2 Penilaian Sasaran Kerja Pegawai meliputi aspek: (a) Objektif, adalah penilaian terhadap pencapaian prestasi kerja sesuai dengan keadaan yang sebenarnya tanpa dipengaruhi oleh pandangan atau penilaian subjektif pribadi dari pejabat penilai; (b) Terukur, adalah penilaian prestasi kerja yang dapat diukur secara kuantitatif dan kualitatif; (c) Akuntabel, adalah seluruh hasil penilaian prestasi kerja harus dapat dipertanggungjawabkan kepada pejabat yang berwenang; (d) Partisipatif, adalah seluruh proses penilaian prestasi kerja dengan melibatkan secara aktif antara pejabat penilai dengan PNS yang dinilai; dan (e) Transparan, adalah seluruh proses dan hasil penilaian pretasi kerja bersifat terbuka dan tidak bersifat rahasia.

Kemudian dijelaskan dalam Penjelasan Atas Peraturan Pemerintah Nomor 46 Tahun 2011 Tentang Penilaian Prestasi Kerja Pegawai Negeri Sipil Pasal 7 Ayat 2 Penilaian Sasaran Kerja Pegawai meliputi aspek: (a) Kuantitas, adalah ukuran jumlah atau banyaknya hasil kerja yang dicapai; (b) Kualitas, adalah ukuran mutu setiap hasil kerja yang dicapai; (c) Waktu, adalah ukuran lamanya proses setiap hasil kerja yang dicapai; dan (d) Biaya, adalah besaran jumlah anggaran yang digunakan setiap hasil kerja.

Peraturan Pemerintah Nomor 46 Tahun 2011 tentang Penilaian Prestasi Kerja Pegawai Negeri Sipil Pasal 7 menjelaskan: Penilaian Prestasi Kerja Pegawai meliputi aspek Kuantitas, Kualitas, Waktu dan Biaya. Aspek tersebut sesuai dengan karakteristik, sifat dan jenis kegiatan pada masing-masing unit kerja. Setiap Instansi menyusun dan menetapkan standar teknis kegiatan sesuai dengan karaktertistik, sifat, jenis kegiatan dan kebutuhan tugas masingmasing jabatan. Menurut Peraturan Kepala Badan Kepegawaian Nasional Negara Nomor 1 Tahun 2013 tentang Ketentuan Pelaksanaan Peraturan Pemerintah Nomor 46 Tahun 2011 tentang Penialaian Prestasi Kerja Pegawai Negeri Sipil Bab 5 Angka 1 dan 2 dalam penilaian prestasi kerja PNS dinyatakan dengan angka sebutan sebagai berikut: 91-ke atas : Sangat Baik; 76-90 : Baik; 61-75 : Cukup; 51-60 : Kurang; dan 50 ke bawah : Buruk. Penialaian Prestasi Kerja dilaksanakan oleh Pejabat Penilai sekali dalam 1 (satu) tahun. Penialain Prestasi Kerja dilakukan setiap akhir Desember pada tahun yang bersangkutan dan paling lambat akhir Januari tahun berikutnya.

\section{METODE}

Pelaksanaan kegiatan penelitian merupakan proses mengamati pada setiap gejala yang tampak pada suatu keadaan tertentu untuk mendapatkan data. Untuk memperoleh data yang akurat maka diperlukan suatu metode penelitian untuk mempermudah dan menentukan penulis dalam melakukan penelitian sesuai dengan ketentuan dan prosedur penelitian. Selain itu dengan adanya metode, penelitian dapat berjalan dengan baik dan sejalan dengan arah permasalahan yang penulis teliti. Dalam penelitian ini penulis akan menggunakan metode kualitatif secara diskriptif dengan pendekatan induktif. Penelitian deskriptif bertujuan membuat gambaran secara sistematis mengenai fenomena yang terjadi di lapangan. Pendekatan induktif yang digunakan peneliti adalah pendekatan induktif yang bersifat field research (penelitian lapangan). Menurut Erliana (2011) menjelaskan bahwa "pendekatan induktif itu mendasarkan diri pada hal-hal yang bersifat khusus (fakta), kemudian mengambil kesimpulan umum apakah sesuai 
dengan dalil, hukum, dan teori yang ada. Mulai dari penganalisaan kondisi lapangan, dihubungakan dengan dalil, teori, hukum dan selanjutnya dibuat kesimpulan". Pada saat proses pengamatan, penulis melakukan analisis yaitu mencari kejadian-kejadian atau fenomena-fenomena nyata berdasarkan informasi yang terkumpul serta berdasarkan teori yang menjadi dasar analisa, sehingga akan diperoleh kejelasan tentang pokok-pokok permasalahan dan apa sajakah faktor-faktor yang mempengaruhinya. Penulis mencoba untuk menyimpulkan yaitu untuk mendeskripsikan bagaimana Penilaian Prestasi Kerja Pegawai Negeri Sipil di Badan Kepegawaian dan Pengembangan Sumber Daya Manusia Daerah Kabupaten Bungo.

\section{HASIL}

\section{Sasaran Kerja Pegawai}

Kuantitas

Kuantitas adalah ukuran jumlah atau banyaknya hasil kerja yang dicapai. Penilaian capaian Sasaran Kerja Pegawai (SKP) diukur dari aspek kuantitas dilakukan dengan membandingkan antara Realisasi Output (RO) dengan Target Output dikalikan 100 (seratus). Hasil dari perhitungan ini dapat diartikan bahwa apabila nilai Realisasi Output sama dengan atau melebihi dari nilai Target Output menunjukan bahwa prestasi kerja pegawai negeri sipil yang baik begitu juga sebaliknya apabila nilai Realisasi Output di bawah nilai Target Output menunjukan bahwa prestasi pegawai negeri sipil yang buruk. Perhitungan capaian Sasaran Kerja Pegawai (SKP) dalam Peraturan Kepala Badan Kepegawaian Nasional Nomor 01 Tahun 2013 berdasarkan aspek kuantitas, dengan rumus:

Sasaran Kerja Pegawai (SKP) $=\frac{\text { Realisasi Output }}{\text { Target Output }} \times 100$

Salah satu contoh penghitungan aspek kuantitas dengan pejabat penilai Kepala Sub Bagian Umum dan Kepegawaian Badan Kepegawaian dan Pengembangan Sumber Daya Manusia Daerah Kabupaten Bungo dan Pegawai Negeri Sipil yang dinilai adalah Pengadministrasi Surat Dinas. Dalam dokumen SKP pada Tahun 2018 Target untuk kuantitas/output adalah 1200 surat dan berhasil terealisasi sebanyak 1190 surat, sehingga kuantitas pekerjaan apabila dihitung menggunakan rumus aspek kuantitas akan mendapatkan nilai 99,16. Jika dimasukan ke dalam rumus akan menjadi sebagai berikut :

Kuantitas $=\frac{1190}{1200} \times 100=99,16$

Berdasarkan wawancara dengan Kepala Sub Bagian Umum dan Kepegawaian Badan Kepegawaian dan Pengembangan Sumber Daya Manusia Daerah Kabupaten Bungo, pada tanggal 14 Januari 2019 mengatakan bahwa "Memang pegawai sudah mengerjakan kontrak kerja sesuai dengan apa yang sudah dibuat, akan tetapi masih ada beberapa yang belum terlaksana dengan maksimal". Beberapa pegawai negeri sipil Badan Kepegawaian dan Pengembangan Sumber Daya Manusia Daerah Kabupaten Bungo juga mengatakan hal yang sama bahwa kuantitas/output belum terlaksana dengan baik.

Sementara itu berdasarkan wawancara dengan Kepala Bidang Pengembangan Sumber Daya Manusia Badan Kepegawaian dan Pengembangan Sumber Daya Manusia Daerah Kabupaten Bungo, pada tanggal 16 Januari 2019 pukul 11.32 WIB menyatakan bahwa: "Dalam pembuatan SKP hampir semua pegawai membuat SKP pada akhir tahun bahkan awal tahun selanjutnya. Hal ini menyebabkan hasil kuantitas output yang dibuat atau dilaporkan bersifat semu dan tidak obyektif karena belum ada bukti nyata di dalam realisasi outputnya sehingga dalam mengisi target output dan realisasi outputnya hanya dikarang saja.

Berdasarkan hasil pengamatan di atas penulis menarik kesimpulan bahwa kuantitas/output sasaran kerja pegawai negeri sipil di Badan Kepegawaian dan Pengembangan Sumber Daya Manusia Daerah Kabupaten Bungo telah terlaksana dengan cukup baik dari segi penetapan target dan realisasi kuantitas/output cukup obyektif dan sudah memenuhi target. Dalam mengukur kuantitas ini, tentunya tidak dilihat dari seberapa banyak ataupun seberapa besar beban kerja yang diselesaikan pegawai setiap tahunnya, tentunya juga harus dikaitkan dengan aspek kualitas, waktu dan biaya disertai dengan bukti nyata dari realisasi output yang telah dikerjakan.

\section{Kualitas}

Kualitas adalah ukuran mutu setiap hari kerja yang dicapai. Penilaian capaian Sasaran Kerja Pegawai (SKP) diukur dari aspek kualitas dilakukan dengan membandingkan antara Realisasi Kualitas (RK) dengan Target Kualitas (TK) dikalikan 100. Hasil dari perhitungan ini dapat diartikan bahwa semakin tinggi realisasi kualitas dari target kualitas yang direncanakan, menunjukan tingkat prestasi kerja yang semakin baik, atau sebaliknya semakin rendah realisasi kualitas dari target kualitas yang direncanakan menunjukan tingkat prestasi kerja yang semakin buruk. Penialaian Prestasi Kerja Pegawai Negeri Sipil mengungapkan aspek kualitas dihitung dengan rumus: 
Salah satu contoh penghitungan aspek kualitas adalah antara pejabat penilai selaku Kepala Sub Bidang Informasi dan Pengembangan SDM Daerah Badan Kepegawaian dan Pengembangan Sumber Daya Manusia Daerah Kabupaten Bungo dengan Pegawai Negeri Sipil yang diniliai adalah selaku Pengolah Data Kesejahteraan Pegawai. Dalam dokumen SKP pada Tahun 2018 Target untuk Kualitas/mutu adalah 100 dan setelah dilaksanakan berhasil mendapatkan nilai 81. Sehingga kualitas pekerjaan apabila dihitung menggunakan rumus aspek kualitas akan mendapatkan nilai 81. Jika dimasukan ke dalam rumus akan menjadi sebagai berikut:

Kualitas $=\frac{81}{100} \times 100=81$

Kriteria Nilai Kualitas dalam Sasaran Kerja Pegawai, nilai 81 menerangkan bahwa Hasil kerja Pegawai Negeri Sipil mempunyai 1 (satu) atau 2 (dua) kesalahan kecil, tidak ada kesalahan besar, revisi dan pelayanan sesuai standar yang telah ditentukan dan lain-lain. Dalam wawancara dengan Kepala Sub Bidang Informasi dan Kesejahteraan Pegawai Badan Kepegawaian dan Pengembangan Sumber Daya Manusia Daerah Kabupaten Bungo, tanggal 16 Januari 2019 mengatakan bahwa "Hasil dari kualitas pekerjaan pegawai selama saya berada di sini cukup baik hampir tidak ada kesalahan dan melakukan pelayanan sesuai dengan SOP yang berlaku. Beberapa pegawai negeri sipil di Badan Kepegawaian dan Pengembangan Sumber Daya Manusia Daerah Kabupaten Bungo juga menyatakan bahwa mutu/kualitas kerja mereka sudah sebagaimana standar mutu kerja dan di atas rata-rata. Hal yang sama juga disampaikan oleh salah satu pegawai pejabat fungsional Badan Kepegawaian dan Pengembangan Sumber Daya Manusia Daerah Kabupaten Bungo, pada tanggal 17 Januari 2019 yang mengatakan bahwa "mutu kualitas kerja saya rasa baik karena sudah mengerjakan tupoksi pekerjaan saya sesuai dengan target". Berdasarkan hasil pengamatan penulis saat melakukan magang di Badan Kepegawaian dan Pengembangan Sumber Daya Manusia Daerah Kabupaten Bungo nilai mutu kualitas pekerjaan pegawai negeri sipil berkisar 80-90 sehingga sudah dapat dikatakan baik.

\section{Waktu}

Waktu adalah ukuran lamanya proses setiap hasil kerja yang dicapai. Penilaian capaian Sasaran Kerja Pegawai (SKP) diukur dari aspek waktu yang dihitung dari nilai tertimbang $(\mathrm{NT}=1,76)$ dikalikan dengan Target Waktu (TW) dikurangi Realisasi Waktu (RW) dibagi Target Waktu (TW) dikalikan 100. Hasil dari perhitungan ini dapat diartikan bahwa semakin lama realisasi waktu yang digunakan dari target waktu yang direncanakan menunjukan tingkat prestasi kerja yang semakin buruk atau sebaliknya semakin cepat realisasi waktu dari target waktu yang direncanakan (maksimal efisiensi waktu sampai dengan 24\%), menunjukan tingkat prestasi kerja yang semakin baik atau sangat baik. Untuk mengetahui persentase efisiensi waktu dari target waktu yang ditentukan perhitungannya menggunakan rumus:

Persentase Efisiensi Waktu $=100 \%-\frac{\text { Realisasi Waktu }}{\text { Target Waktu }} \times 100$

Salah satu contoh penghitungan aspek waktu adalah antara pejabat penilai selaku Kepala Sub Bidang Informasi dan Pengembangan SDM Daerah Badan Kepegawaian dan Pengembangan Sumber Daya Manusia Daerah Kabupaten Bungo dengan Pegawai Negeri Sipil yang dinilai, selaku Pengolah Data Kesejahteraan Pegawai. Dalam dokumen SKP pada Tahun 2018 Target untuk Waktu adalah selama 12 Bulan dan setelah dilaksanakan berhasil diselesaikan selama 12 Bulan. Sehingga waktu pekerjaan apabila dihitung menggunakan rumus aspek kualitas akan mendapatkan nilai $0 \%$ atau sangat baik. Jika dimasukan ke dalam rumus akan menjadi sebagai berikut:

Kualitas $=100 \%-\left(\frac{12}{12} \times 100\right)=0 \%$

Wawancara dengan Kepala Sub Bidang Penggajian dan Identitas Pegawai Badan Kepegawaian dan Pengembangan Sumber Daya Manusia Daerah Kabupaten Bungo, pada tanggal 16 Januari 2019 WIB mengatakan bahwa: "Pengerjaan Sasaran Kerja Pegawai masih dilaksanakan dengan lambat karena kurangnya sosialisasi tentang Penilaian Prestasi Kerja Pegawai Negeri Sipil. Hanya beberapa pegawai yang baru mengerjakan saat ini dan yang lain masih belum mengerjakan. Bahkan masih ada dari mereka yang harus dipandu oleh pegawai lain untuk membuat Sasaran Kerja Pegawainya sendiri.

\section{Biaya}

Biaya adalah besaran jumlah anggaran yang digunakan setiap hasil kerja. Penilaian capaian Sasaran Kerja Pegawai (SKP) diukur dari aspek biaya dihitung dari nilai tertimbang $(\mathrm{NT}=1,76)$ dikalikan dengan Target Biaya $(\mathrm{TB})$ dikurangi Realisasi Biaya (RB) dibagi dengan Target Biaya (TB) dikalikan 100. Hasil dari perhitungan ini dapat diartikan bahwa semakin besar realisasi biaya yang dipergunakan dari target biaya yang direncanakan, menunjukan 
Ismail Buhari, Penilaian Prestasi Kerja Pegawai Negeri Silpil di Badan Kepegawaian dan Pengembangan Sumber Daya Manusia Daerah Kabupaten Bungo

tingkat prestasi kerja yang semakin buruk atau sebaliknya apabila semakin kecil realisasi biaya dicapai dari target biaya yang direncanakan (maksimal efisiensi biaya sampai dengan 24\%), menunjukan tingkat prestasi kerja yang semakin baik atau sangat baik. untuk mengetahui persentase efisiensi biaya dari target biaya yang ditentukan perhitungannya menggunakan rumus:

Persentase Efisiensi Biaya $=100 \%-\frac{\text { Realisasi Biaya }}{\text { Target Waktu }} \times 100$

Hasil wawancara penulis dengan para pegawai negeri sipil di Badan Kepegawaian dan Pengembangan Sumber Daya Manusia Daerah Kabupaten Bungo pada saat melaksanakan kegiatan penelitian menyatakan bahwa memang dalam setiap kegiatan atau melaksanakan program sudah ada anggaran biayanya sehingga bisa terlaksana dengan baik dan sesuai dengan target. Hal yang sama juga dikatakan oleh Kepala Badan Kepegawaian dan Pengembangan Sumber Daya Manusia Daerah Kabupaten Bungo, mengungkapkan dalam wawancara pada tanggal 15 Januari 2019 bahwa dalam penyelenggaraan pelayanan pemerintahan khususnya di kantor BKPSDMS Bungo semua kegiatan sudah diatur anggarannya sehingga pegawai sudah diimbau untuk menggunakan segala sumber daya keuangan dengan bijak dan digunakan untuk penyelesaian tugas pekerjaan agar penyerapan anggaran tinggi"'. Dari hasil wawancara di atas penulis menyimpulkan bahwa Sasaran Kerja Pegawai membuat perubahan pada sistem penilaian kinerja, karena lebih objektif dalam pelaksanaan penilaian dan dititik beratkan pada beban kerja dan tanggung jawab.

\section{Perilaku Kerja}

Orientasi Pelayanan

Dijelaskan dalam Penjelasan Atas Peraturan Pemerintah Nomor 46 Tahun 2011 tentang Penilaian Prestasi Kerja Pegawai Negeri Sipil Pasal 12 Ayat 1 bahwa Orientasi Pelayanan adalah sikap dan perilaku kerja PNS dalam memberikan pelayanan terbaik kepada yang dilayani antara lain meliputi masyarakat, atasan, rekan sekerja, unit kerja terkait, dan/atau instansi lain. Badan Kepegawaian dan Pengembangan Sumber Daya Manusia Daerah Kabupaten Bungo termasuk salah satu instansi terbaik dalam hal pemberian layanan di Kabupaten Bungo. Pada saat wawancara dengan Kepala Bidang Pengangkatan dan Pemberhentian Pegawai Badan Kepegawaian dan Pengembangan Sumber Daya Manusia Daerah Kabupaten Bungo, pada tanggal 16 Januari 2019 mengatakan bahwa: "Kami disini bersama Bapak Kepala Badan sangat berkomitmen untuk menghilangkan budaya-budaya KKN. Alhamdulillah saat ini belum ada laporan mengenai kegiatan pungli salah satu contoh dalam kegiatan seleksi CPNS yang sudah berlangsung beberapa bulan yang lalu. Berdasarkan hasil wawancara di atas diketahui bahwa, pegawai negeri sipil di Badan Kepegawaian dan Pengembangan Sumber Daya Manusia Daerah Kabupaten Bungo sudah menunjukan pelayanan dengan berorientasikan kualitas kerja sehingga sudah bisa dikatakan dalam kategori baik.

\section{Integritas}

Integritas adalah kemampuan untuk bertindak sesuai dengan nilai, norma dan etika dalam organisasi. Organisasi akan sulit, untuk maju ketika integritas dari pegawainya buruk. Pegawai negeri sipil sebagai bagian dari aparatur sipil negara dituntut untuk mempunyai integritas yang tinggi guna menunjang kinerja yang lebih baik. Tentu saja integritas yang baik akan berdampak kepada kepuasan masyarakat yang dilayani. Kepala Sub Bagian Formasi dan Pengadaan Pegawai Badan Kepegawaian dan Pengembangan Sumber Daya Manusia Daerah Kabupaten Bungo, pada tanggal 16 Januari 2019 mengatakan bahwa "integritas/kejujuran mempunyai perananan yang sangat penting dalam mempengaruhi kinerja seorang pegawai". Kepala Badan Kepegawaian dan Pengembangan Sumber Daya Manusia Daerah Kabupaten Bungo, pada tanggal 15 Januari 2019 menyatakan bahwa "Integritas pegawai disini masih perlu ditingkatkan masing-masing pribadi ASN. Berdasarkan data di lapangan integritas pegawai negeri sipil Badan Kepegawaian dan Pengembangan Sumber Daya Manusia Daerah Kabupaten Bungo cukup baik, akan tetapi masih perlu ditingkatkan lagi baik dari pribadi masing-masing maupun pembinaan dan pemberian pelatihan dari instansi yang bersangkutan tentang integritas yang ideal bagi ASN guna bisa diaplikasikan di lapangan.

\section{Komitmen}

Komitmen merupakan suatu kemauan dan kemampuan untuk menyalaraskan sikap, tindakan dan prilaku Pegawai Negeri Sipil untuk mewujudkan tujuan organisasi dengan mengutamakan kepentingan dinas dan organisasi dari pada kepentingan diri sendiri, seseorang, dan/atau golongan. Hasil wawancara dengan Kepala Sub Bidang Pengembangan Pegawai Badan Kepegawaian dan Pengembangan Sumber Daya Manusia Daerah Kabupaten Bungo, pada tanggal 16 Januari 2019 menyatakan bahwa "komitmennya yaitu aparatur sipil negara harus disiplin dalam segala hal. Mulai dari disiplin waktu, disiplin dalam integritas diri, dan disiplin kinerja. Dengan kata lain bahwa komitmen dari pegawai negeri sipil di Badan Kepegawaian dan Pengembangan Sumber Daya Manusia Daerah Kabupaten Bungo sudah baik, akan tetapi masih perlu ditingkatkan lagi. Pekerjaan yang diberikan sudah dikerjakan 
Ismail Buhari, Penilaian Prestasi Kerja Pegawai Negeri Silpil di Badan Kepegawaian dan Pengembangan Sumber Daya Manusia Daerah Kabupaten Bungo

dengan penuh rasa tanggung jawab untuk dapat menyelesaikan dengan baik dan sudah mempunyai komitmen yang cukup baik tentang kemajuan kinerja pribadi masing-masing.

\section{Disiplin}

Disiplin merupakan kesanggupan pegawai negeri sipil untuk mentaati kewajiban dan menghindari larangan yang ditentukan dalam peraturan perundang-undangan dan/atau peraturan kedinasan yang apabila tidak ditaati atau dilanggar dijatuhi hukuman disiplin. Berdasarkan data di lapangan para pegawai negeri sipil di Badan Kepegawaian dan Pengembangan Sumber Daya Manusia Daerah Kabupaten Bungo memiliki disiplin baik. Salah satu bukti yang didapat oleh penulis pada saat kegiatan penelitian adalah pegawai negeri sipil selalu melaksanakan apel pagi tepat waktu. Kegiatan ini rutin dilakukan setiap hari kerja di Badan Kepegawaian dan Pengembangan Sumber Daya Manusia Daerah Kabupaten Bungo. Dengan kata lain tingkat kedisiplinan pegawai negeri sipil di Badan Kepegawaian dan Pengembangan Sumber Daya Manusia Daerah Kabupaten Bungo sudah baik, pegawai sudah memiliki kesadaran diri untuk mengikuti segala aturan yang ada. Akan tetapi masih ada beberapa yang masih perlu dilakukan pembinaan dan ditingkatkan tingkat kedisiplinannya terkhusus untuk disiplin yang bersangkutan dengan pelaksanaan tugas pokok dan fungsi.

\section{Kerjasama}

Kerjasama merupakan kemauan dan kemampuan pegawai negeri sipil untuk bekerjasama dengan rekan kerja, atasan, bawahan, dalam unit kerjanya serta instansi lain dalam menyelesaikan suatu tugas dan tanggung jawab yang ditentukan, sehingga mencapai daya guna dan hasil guna yang sebesar-besarnya. Kerjasama merupakan salah satu unsur yang sangat penting di dalam organisasi. Adanya kerjasama membuat organisasi semakin solid dan kompak dalam mencapai tujuan organisasinya. Kerjasama dapat secara horizontal maupun secara vertikal. Hasil dari wawancara dengan Kepala Badan Kepegawaian dan Pengembangan Sumber Daya Manusia Daerah Kabupaten Bungo, pada tanggal 15 Januari 2019 mengatakan bahwa Kerja sama pegawai sudah bagus, terbukti dari suasana kekeluargaan yang dibangun oleh sesame pegawai dalam menjalankan tugas akan tetapi masih dalam koridor secara profesional. Antar bagian juga saling bantu membantu dalam menyelesaikan tugas yang dianggap membutuhkan sumber daya yang lebih. Hal ini juga didukung dengan hasil wawancara dengan salah satu pegawai (pejabat fungsional) di Badan Kepegawaian dan Pengembangan Sumber Daya Manusia Daerah Kabupaten Bungo, pada tanggal 17 Januari 2019 yang mengatakan bahwa "Kerjasama di sini sudah cukup baik, alasannya rekan-rekan yang ada disini selalu bersedia untuk dimintai bantuan dalam menyelesaikan tugas atau permasalahan yang ada. Berdasarkan hasil wawancara dari beberapa orang staf yang ada di Badan Kepegawaian dan Pengembangan Sumber Daya Manusia Daerah Kabupaten Bungo bahwa kerjasama yang terjalin antar personil pegawai negeri sipil sudah terlaksana dengan baik dilihat dari segi aturan yang berlaku dan kenyataan yang terjadi di lapangan.

\section{Kepemimpinan}

Kepemimpinan adalah kemampuan dan kemauan pegawai negeri sipil untuk memotivasi dan mempengaruhi bawahan atau orang lain yang berkaitan dengan bidang tugasnya demi tercapainya tujuan organisasi. Penulis memperoleh data dari wawancara dengan Kepala Sub Bidang Pengembangan Pegawai Badan Kepegawaian dan Pengembangan Sumber Daya Manusia Daerah Kabupaten Bungo, pada tanggal 16 Januari 2019 mengatakan bahwa "kepemimpinan dari atasan saat ini menerapkan pola kekeluargaan. Artinya Kepala Badan mampu menciptakan suasana yang baik di dalam organisasi sehingga para pegawai tidak merasa tertekan dalam melaksanakan tugas. Halhal tersebut di atas penulis menyimpulkan bahwa kepemimpinan di Badan Kepegawaian dan Pengembangan Sumber Daya Manusia Daerah Kabupaten Bungo sudah dinilai baik, kepemimpinan dari pimpinan organisasi mampu menciptakan suasana yang baik di dalam organisasi.

\section{SIMPULAN}

Penilaian prestasi kerja di Badan Kepegawaian dan Pengembangan Sumber Daya Manusia Daerah Kabupaten Bungo cukup efektif, hal ini tampak dari:

a. Sasaran Kerja Pegawai (SKP) di Badan Kepegawaian dan Pengembangan Sumber Daya Manusia Daerah Kabupaten Bungo yang sudah tercapai walaupun belum sepenuhnya baik.

b. Perilaku Pegawai masih ada yang belum mempunyai jiwa profesional dalam bekerja dan menjalankan tugas yang diberikan.

c. Masih ada beberapa pegawai yang belum paham dan mengerti mengenai Peraturan Pemerintah Nomor 46 Tahun 2011 tentang Penilaian Prestasi Kerja Pegawai Negeri Sipil. 
Ismail Buhari, Penilaian Prestasi Kerja Pegawai Negeri Silpil di Badan Kepegawaian dan Pengembangan Sumber Daya Manusia Daerah Kabupaten Bungo

\section{DAFTAR PUSTAKA}

Arikunto, S. (2013). Manajemen Penelitian. Jakarta : Bineka Cipta

Bungin, B. (2011). Penelitian Kualitatif, Komnunikasi, Ekonomi, Kebijakan Publik, dan Ilmu Sosial Lainnya. Jakarta: Kencana

Fahmi, I. (2011). Manajemen Kinerja Teori dan Aplikasi. Bandung: PT. CV. Alfabeta.

Harsono. (2011). Sistem Administrasi Kepegawaian. Bandung: Fokus Media.

Hasan, E. (2011). Filsafat Ilmu dan Metodologi Penelitian Ilmu Pemerintahan. Bogor: Ghalia Indonesia.

Hasibuan, M. S. P. (2016). Manajemen Sumber Daya Manusia Edisi Revisi. Jakarta: Bumi Akasara

Mangkunegara, A. P. (2012). Evaluasi Kinerja SDM. Bandung: PT. Refika Aditama.

Nazir, M. (2013). Metode Penelitian. Bogor: Ghalia Indonesia

Noor, J. (2014). Metodologi Penelitian Skripsi, Tesis, Disertasi, dan Karya Ilmiah. Jakarta: Kencana

Riduwan, (2010), Metode \& Teknik Menyusun Proposal Penelitian. Bandung: Alfabeta

Sedarmayanti. (2013). Manajemen Sumber Daya Manusia Reformasi Birokrasi dan Manajemen Pegawai Negeri Sipil. Bandung: PT. Refika Aditama

Siagian, S. P. (2016). Manajemen Sumber Daya ManusiaI. Jakarta: Bumi Aksara.

Sudarmanto, (2009). Kinerja dan Pengembangan Kompetensi SDM. New York: Addison-Wesley Publishing Company

Sugiyono. (2014). Metode Penelitian Kuantitatif Kualitatif dan R\&D. Bandung: CV. Alfabeta.

Supriatna, T. dan Sukiasa, A. (2010). Manajemen, Kepemimpinan, dan Sumber Daya Aparatur. Bandung: CV. Indra Prahasta.

Terry, R. G. dan Rue, L. W. (2014). Dasar-Dasar Manajemen. Jakarta: PT. Bumi Aksara.

Widjaja, H. (2007). Otonomi Daerah dan Daerah Otonom. Jakarta: PT. Rajagrafindo Persada.

Undang-Undang Republik Indonesia Nomor 43 Tahun 1999 tentang Pokok-Pokok Kepegawaian

Undang-Undang Republik Indonesia Nomor 5 Tahun 2014 tentang Aparatur Sipil Negara

Undang - Undang Republik Indonesia Nomor 23 Tahun 2014 tentang Pemerintahan Daerah

Peraturan Pemerintah Nomor 46 Tahun 2011 tentang Penilaian Prestasi Kerja Pegawai Negeri Sipil

Peraturan Pemerintah Nomor 18 Tahun 2016 tentang Perangkat Daerah

Peraturan Kepala Badan Kepegawaian Nasional Negara Nomor 1 Tahun 2013 tentang Ketentuan Pelaksanaan Peraturan Pemerintah Nomor 46 Tahun 2011 tentang Penialaian Prestasi Kerja Pegawai Negeri Sipil

Peraturan Rektor Institut Pemerintahan Dalam Negeri Nomor 06 Tahun 2017 tentang Pedoman Penulisan Laporan Akhir dan Skripsi Institut Pemerintahan Dalam Negeri Tahun Akademik 2017/2018 